\title{
Upstream guppies (Poecilia reticulata, Peters, 1859) go against the flow
}

\author{
Ryan Simon Mohammed ${ }^{1,2,5}$, Cock van Oosterhout ${ }^{3}$, Bettina Schelkle ${ }^{4}$, \\ Joanne Cable \& Mark McMullan ${ }^{3}$ \\ ${ }^{I}$ Department of Life Sciences, The University of the West Indies, St Augustine, Trinidad, West Indies \\ ${ }^{2}$ Aquaculture Association of Trinidad and Tobago, West Indies \\ ${ }^{3}$ School of Environmental Sciences, University of East Anglia, Norwich Research Park, \\ Norwich NR4 7TJ, United Kingdom \\ ${ }^{4}$ School of Biosciences, Cardiff University, Cardiff CF10 3AX, United Kingdom \\ ${ }^{5}$ Corresponding author: Ryan Simon Mohammed, e-mail: rmohammed@gmail.com
}

MOHAMMED, R.S., VAN OOSTERHOUT, C., SCHELKLE, B., CABLE, J. \& MCMULLAN, M. Upstream guppies (Poecilia reticulata, Peters, 1859) go against the flow. Biota Neotrop. 12(3): http://www.biotaneotropica. org.br/v12n3/en/abstract?article+bn01512032012

\begin{abstract}
Guppies (Poecilia reticulata Peters 1859) in lakes and from captive-bred populations are predicted to show little rheotaxis compared to conspecifics in a stream environment that are regularly exposed to flash floods associated with involuntary downstream migration. Here we test this hypothesis using an artificial stream, examining guppies of two wild riverine populations, one lake population, and one ornamental strain. Guppies from the most upstream riverine habitat show the most pronounced rheotaxis and are less likely to be swept downstream during flooding events. However, there is no significant difference between guppies from the lowland riverine habitat, the Pitch Lake and ornamental strain. We propose that station-keeping behaviours are most strongly selected in the upstream population because large spatial differences exist in ecology and environment between up- and downstream habitats. Given that these sites are separated by barrier waterfalls that prevent compensatory upstream migration, natural selection operates particularly strong against upstream guppies that have been displaced downstream during flooding events.
\end{abstract}

Keywords: Guppy (Poecilia reticulata), rheotaxis, swimming behaviour, migration, natural selection.

MOHAMMED, R.S., VAN OOSTERHOUT, C., SCHELKLE, B., CABLE, J. \& MCMULlAN, M. Gupies (Poecilia reticulata, Peters, 1859) de áreas de cabeceira se posicionam contra a corrente. Biota Neotrop. 12(3): http://www.biotaneotropica.org.br/v12n3/pt/abstract?article+bn01512032012

Resumo: Populações de guppies (Poecilia reticulata Peters) que vivem em lagos e em cativeiro podem demonstrar menos reotaxia em comparação com populações que habitam rios e que estão frequentemente expostas a enchentes e que provocam a migração involuntária para jusante. Neste trabalho, vamos testar esta hipótese num rio artificial utilizando guppies de duas populações selvagens que habitam em rios, uma população que habita em lagos, e uma linhagem ornamental. Os resultados demonstram que os guppies de rios que provêm de localidades a montante demonstram maior reotaxia, diminuindo assim probabilidade de serem arrastados para jusante em períodos de enchentes. No entanto, não foram encontradas diferenças significativas entre guppies de localidades a jusante, do lago Pitch ou ornamentais. Este resultado pode dever-se ao facto de existirem grandes diferenças ecológicas entre os habitats localizados a jusante e a montante dos rios. Devido ao facto de estas localidades estarem separadas por cachoeiras, impossibilitando a migração rio-acima, a seleção natural poderá estar a actuar contra guppies que sejam arrastados rio abaixo durantes os períodos de cheias

Palavras-chave: Guppy (Poeciliareticulata), reotaxia, piscina comportamento, migração, seleção natural. 


\section{Introduction}

Many freshwater fish species have an innate response to orientate their bodies in water currents, a phenomenon known as positive rheotaxis (Northcutt 1997). Unlike species without active swimming abilities or other station-keeping adaptations (e.g. Blake et al. 2007), this innate swimming response prevents the inevitable extinction of closed populations subject to dominant downstream migration (cf. Müller 1954 'drift paradox'). Rheotaxis also maximizes perception of chemical cues, interception of prey, and minimizes energy expenditure (Montgomery et al. 1999). From an evolutionary perspective, rheotaxis allows animals to maintain a position within a stream (station-keeping) which avoids potential fitness costs involved with emigration (McCormick et al.1998).

Guppies (Poecilia reticulata Peters, 1859) can be found in a wide range of habitats, from riverine environments to lakes (Deacon et al. 2011). This species is also common in the aquarium trade; they have been bred and kept in captivity since the 1920s (Deacon et al. 2011). The hydrodynamic environment the fish in wild populations encounter is dramatically different. In the mountainous region of the Caroni Drainage in Trinidad, the fish are exposed to seasonal flash-flooding events, coinciding with the wet-season rains (van Oosterhout et al. 2007a). In contrast, the guppies from ornamental strains in aquaculture and those occurring in natural lakes never encounter high water velocities or flash-flooding. For example, the Pitch Lake in Trinidad is a flat crater with pitch and asphalt folds that create several freshwater pools. It is approximately $0.8 \mathrm{~km}^{2}$ and guppies in this habitat experience little or no water currents. Here we hypothesize that guppies have adapted to the hydrodynamic conditions typical for their habitat. In particular, we predict that the guppies in the Pitch Lake may have lost their innate rheotaxic behaviours. Similarly, we predict that due to relaxed natural selection in captivity (van Oosterhout et al. 2007b) ornamental strain guppies will show little station-keeping behaviour. In contrast, guppies from a riverine habitat are predicted to show more pronounced rheotaxis and station-keeping.

\section{Materials and Methods}

\section{Experimental animals and procedure}

The behaviour of 60 adult guppies from three populations in Trinidad were studied: the Upper Naranjo (UN: Grid Ref. UTM 20P 693443, 1183935), the Lower Aripo (LA: 694432, 1178141) and the Pitch Lake (PL: 650459, 1131727). Additionally, ornamental strain guppies (OS, $\mathrm{n}=20)$ belonging to the Istanbul strain were tested for their rheotactic or station-keeping behaviours. The UN is a small upstream tributary of the Aripo River. The mean water flow rate of upstream sites is significantly higher than in the downstream sites (upstream $\approx 8.7 \mathrm{~cm} . \mathrm{s}^{-1}$; downstream $\approx 5.5 \mathrm{~cm} . \mathrm{s}^{-1}$, see Reznick et al. 2001). This set of populations was chosen to test the hypothesis that riverine fish populations that experience seasonal floods in the wild (i.e. the UN and LA populations) display stronger station-keeping behaviours than guppies from a natural or captive environment with little or no natural water currents (i.e. the PL and the OS guppies). All fish were collected at the end of the dry season (March-June) in 2009 where the water depth and flow rate was comparable to Reznick et al. (2001) observations.

In total, 20 guppies per population with approximately equal sex ratio and similar size range were used: standard length $\mathrm{SL}=12-25 \mathrm{~mm}$, (mean $( \pm \mathrm{SD})$ : $\mathrm{SL}=18.3( \pm 1.2) \mathrm{mm})$. Guppies were maintained in four $80 \mathrm{~L}$ aquaria in groups of 35-60 fish per tank. They were screened for parasites following the protocol described in van Oosterhout et al. (2003) and Schelkle et al. (2009). These screens were conducted because guppies infected with Gyrodactylus spp. are more likely to be swept downstream than uninfected counterparts van (van Oosterhout et al. 2007a). Briefly, guppies were anaesthetised with $0.02 \%$ MS222 and using a stereo-microscope and fibre optic illumination, gyrodactylids were removed with watchmaker's tweezers. Fish were clean of all ectoparasites and showed no symptoms of disease in the two weeks prior to the experiment.

The behaviour of guppies was recorded in an artificial stream (length $\times$ width $\times$ depth $=112.2 \times 12 \times 4.0 \mathrm{~cm}^{3}$ ). The water flow rate was $15.4( \pm 1.2) \mathrm{cm} . \mathrm{s}^{-1}$, comparable to their mean critical swimming speed (Syriatowicz \& Brooks 2004). The artificial stream was divided into 11 segments of $10.2 \mathrm{~cm}$ each, with a downstream weir which led to a small pool. The focal fish was released into the sixth segment in the middle of the stream. Its position was recorded at 5 seconds intervals over a period of 240 seconds. The experiment was terminated after 240 seconds or when the focal fish went across the weir into the pool (i.e. swept downstream). Post release, all monitoring was done via video to avoid disturbance to the fish.

The incidence of guppies being swept downstream was noted, and the average position of a guppy in the river and its mobility (i.e. average distance swum in 5 seconds intervals) during its time in the stream was calculated. A previous study using an artificial stream showed that guppies were not attracted to conspecific chemosensory cues (Archard et al. 2008). Hence, we used tank water that was recycled throughout the experiment. The water temperature was 27.0 $( \pm 1.0){ }^{\circ} \mathrm{C}$ and recordings were made between 0700-1700 $\mathrm{h}$ under indirect natural daylight in June 2009.

\section{Statistical analyses}

A binary logistic regression analysis (logit) with a dichotomous dependent variable ("swept downstream" or "kept station") was used to test whether the incidence that a guppy was swept downstream was explained by the origin of population, sex and SL. The model had three predictors: 'Population' and 'Sex' as fixed factors, and 'SL' as covariate. The model was fitted using an iterative re-weighted least squares algorithm to obtain maximum-likelihood estimates of all parameters. The log-likelihood was used to test whether the coefficients of the predictors were significantly different from zero. A logit link function was used to calculate the odds ratio and its 95\% confidence interval (CI). Differences in the mean position of guppies in the stream between populations, sexes and SL were tested using a General Linear Model (GLM). We also used a GLM to compare the mobility of guppies among populations, sexes and SL. In these models, Population and Sex were fixed factors, and SL was the covariate. We checked whether the data were appropriate for parametric analysis and confirmed homogeneity of variances and normal distributions of residuals. All tests were conducted in Minitab 12.1.

\section{Results}

Guppies from the UN were significantly less likely to be swept downstream than their LA counterparts (Binary Logistic Regression: $Z=-2.47, \mathrm{p}=0.014)$, mean and $5-95 \% \mathrm{CI}$ odds ratio $=0.11(0.02-$ $0.64)$. However, there was no significant difference in the likelihood of fish being displaced downstream between the other populations (OS guppies: $Z=-1.83, \mathrm{p}=0.068$; PL guppies: $Z=-1.25, \mathrm{p}=0.212$ ) (Figure 1). The Sex and SL of guppies did not explain variation in the probability being swept downstream $(Z=0.47, \mathrm{p}=0.636$ and $Z=0.17, \mathrm{p}=0.862$, respectively).

There was a significant difference in the mean position of fish among populations $\left(\mathrm{F}_{3,74}=4.32, \mathrm{p}=0.007\right)$, with the UN being on average most upstream, and the OS the furthest downstream (see 
Figure 2). Fish size (SL) and Sex did not affect the position of fish within the artificial river $\left(\mathrm{F}_{1,74}=0.16, \mathrm{p}=0.692\right.$, and $\mathrm{F}_{1,74}=1.87$, $p=0.161)$. There were significant differences in mobility between the fish of the four populations (GLM: $\left.F_{3,74}=3.71, p=0.015\right)$ without the inclusion of Sex and SL data. However, SL did not explain variation in mobility between the fish (GLM: $\left.\mathrm{F}_{1,74}=0.61, \mathrm{p}=0.438\right)$, and there was no difference between the Sexes (GLM: $\left.F_{1,74}=0.89, p=0.414\right)$. The UN fish were significantly less mobile than fish of the other three populations, moving on average $6.0 \mathrm{~cm}$ per $5 \mathrm{~s}$, compared to 11.4 , 9.1 and $9.3 \mathrm{~cm}$ per $5 \mathrm{~s}$ for the LA, PL and OS guppies, respectively.

\section{Discussion}

Guppies from the upstream population, the Upper Naranjo (UN) were significantly less likely to be flushed downstream than Lower

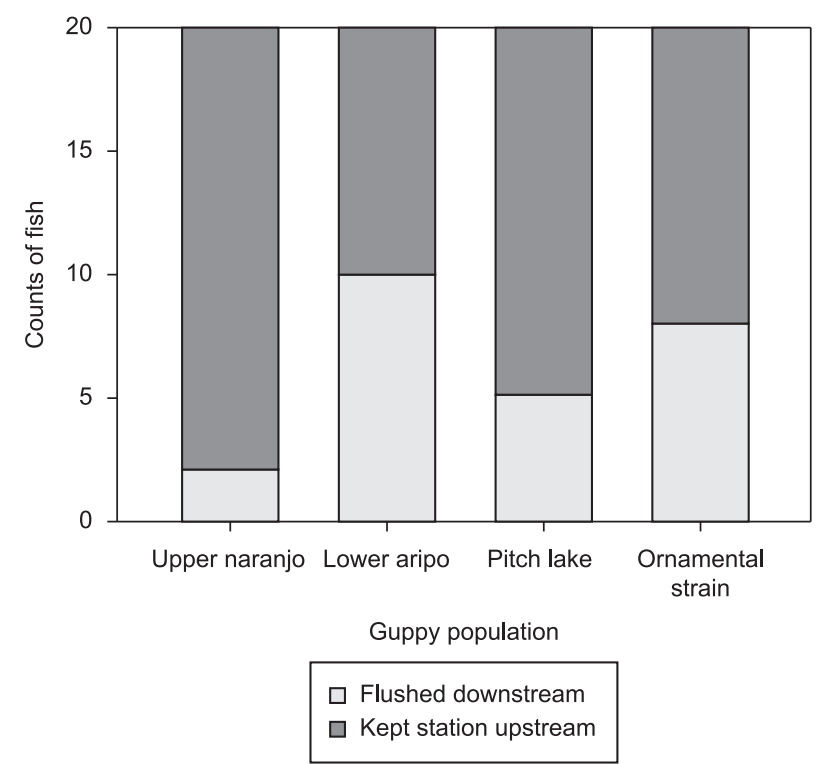

Figure 1. Number of fish that remained stationary and retained their position in the artificial stream (grey bars) and fish swept downstream over the weir into the pool (black bars) in the four populations. UN guppies were significantly less likely to be swept downstream than LA guppies (see text).

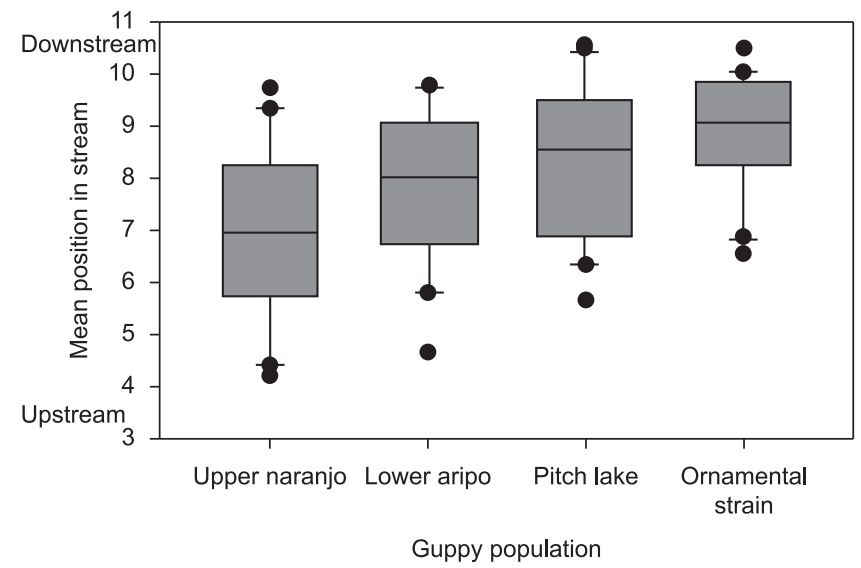

Figure 2. Box plot showing the average position of guppies in the artificial stream. Dots represent outliers, bars show the lower and upper limits and the box represents the first and third quartile value with the median. There was a significant difference between the mean positions of fish among populations (see text).
Aripo (LA), Pitch Lake (PL) and ornamental strain (OS) guppies. We hypothesised that wild fish, experiencing seasonal floods (i.e. the UN and LA populations) should display stronger rheotaxis or station-keeping behaviours than guppies in habitats with little or no natural water currents (i.e. the PL and the OS guppies). The results are inconsistent with our hypothesis, and suggest that the level of rheotaxis of guppies in populations that are not subjected to seasonal flooding is similar to that of guppies occurring in (lowland) rivers which are regularly in spate-conditions.

First, we consider the hypothesis that the relatively reduced level of station-keeping observed in the high-predation LA guppies can be explained by a trade-off between escape-response versus swimming endurance. The UN guppies live a low predation environment, whereas the LA has high predator pressure on the guppies (van Oosterhout et al. 2007). Selection favours enhanced escaperesponse in high predation sites, a behaviour known as fast-start evasion response or c-start (Ghalambor et al. 2004). Could adaptations favouring the c-start compromise rheotaxis and swimming endurance in the high-predation LA? To answer this question we need to consider the station-keeping behaviour of the Pitch Lake and the ornamental guppies, which originate from habitats with little or no predation. Similar to the low-predation UN guppies, these populations do not experience strong selection for c-start. Nevertheless, Pitch Lake and ornamental guppies are equally prone to being swept downstream as the LA guppies. This suggests that the hypothesised trade-off between escape-response versus swimming endurance in the LA cannot be held responsible for reduced station-keeping performance in all three populations (i.e. LA, PL and OS).

Reduced predator fauna has been shown to increase the number of guppies that occupy the fast flowing regions of the river (Kodric-Brown \& Nicoletto 2005). Flow rates in upstream sites are, on average, greater than in downstream sites (Reznick et al. 2001). Furthermore, upstream guppies that are not discouraged (by piscivorous predators) from deeper or faster flowing regions of the river are presumably more likely to develop peduncle muscle in response to exposure to high flow rates (e.g. Nicoletto 1996). Therefore, increased rheotactic behaviour in the UN may be a plastic response to reduced predator fauna in a fast flowing river. Darden \& Croft (2008) found that in high predation (lowland) sites, predation risk is greater in the deeper regions of a river. Interestingly, the authors also found that, in response to male presence, females will move into deeper waters, thereby increasing their predation risk (Darden \& Croft 2008). The authors argue that this behaviour may increase the risk of female predation, but that this cost is balanced by a reduced level of harassment from males. It is conservable that in low predation (upstream) sites males do not suffer such increased predation risk in high flow regions and therefore only those males able to display and maintain their position in faster flowing regions of the river pass on their genes (e.g. Kodric-Brown \& Nicoletto 2005). The findings in the present study and those in previous studies (Kodric-Brown \& Nicoletto 2005, Darden \& Croft 2008) suggest that a reduction in predator fauna in upstream sites may drive both phenotypic plasticity (in development of peduncle muscle) and selection toward increased rheotactic behaviour in the UN guppies.

Fish that are displaced from the UN during seasonal flood events may be prevented from returning upstream by barriers to gene flow such as waterfalls (Crispo et al. 2006, van Oosterhout et al. 2007a). Compensatory upstream migration in the lowlands may allow the return of displaced fish that have not been swept over such barriers (see Barson et al. 2009, Willing et al. 2010). In addition, distinct differences exist in predator and parasite faunas between upland and lowland habitats (Endler 1980, Reznick et al. 2001, Cable \& van Oosterhout 2007). Several translocation experiments have 
shown that guppies are particularly well-adapted to cope with the local biotic and abiotic environmental conditions (e.g. Gordon et al. 2009). For example, guppies that evolved in a low-predation upland habitat have reduced anti-predator responses such as shoaling behaviour (Huizinga et al. 2009). Furthermore, the males tend to be more colourful, which make them vulnerable to visually-hunting predators that are common in the lowland environment (Endler 1995). Consequently, selection will favour behavioural responses that increase site fidelity (Winker et al. 1995, Aparicio \& De Sostoa 1999). It is therefore likely that in the low-predation upland population of the $\mathrm{UN}$, natural selection has promoted flush avoidance behaviour and positive rheotaxis. In contrast, even after downstream displacements during floods, lowland guppies of the LA population will find themselves in a similar, high-predation habitat to which they are adapted. We propose that the combination of a larger flow rate in the upland habitats in combination with the dramatic fitness consequences for upland guppies that are unable to resist flash-flooding has resulted in strong selection for station-keeping in the UN. This could explain why the UN guppies show the highest level of rheotaxis.

Croft et al. (2003) showed sex-biased dispersal in guppies, demonstrating a significant bias for upstream movement by males but not females. In addition, they found a positive correlation between body length and distance moved in females. van Oosterhout et al. (2007a), on the other hand, showed that males with parasite infections were more likely to be swept downstream during wet-season floods than females. The current study did not detect differences in rheotaxic behaviour between the sexes, and the size of fish did not explain differences in this behaviour. Instead, most variation was explained by the population origin of the fish.

Although our data can be explained by differences in selection pressures between populations, we cannot rule out that these results can be explained also by proximate (mechanistic) differences between populations. Future anatomical, behavioural and genetic studies into rheotaxis of guppies seem warranted, as due to the strong gradient in selection pressure the expression of this behaviour should vary predictably across the environment.

\section{Acknowledgements}

We thank Mr and Mrs Rasheed Mohammed for their support, Gabrielle Archard and Thomas Breithaupt for comments on the MS and Raquel S. Xavier for Portuguese translations. This work was supported by a Natural Environment Research Council studentship to $\mathrm{MM}$ (NER/S/A/2005/13362A), a Biotechnology and Biological Sciences Research Council CASE studentship to BS (BB/D526137/1) and a European Community Framework Programme 6 (MTKDCT-2005-030018).

\section{References}

APARICIO, E. \& DE SOSTOA, A. 1999. Pattern of movements of adult Barbus haasi in a small Mediterranean stream. J. Fish Biol. 55(5):10861095 .

ARCHARD, G.A., CUTHILl, I.C., PARTRIDGE, J.C. \& VAN OOSTERHOUT, C. 2008. Female guppies (Poecilia reticulata) show no preference for conspecific chemosensory cues in the field or an artificial flow chamber. Behaviour 145:1329-1346.

BARSON, N.J., CABLE, J. \& VAN OOSTERHOUT, C. 2009. Population genetic analysis of microsatellite variation of guppies (Poecilia reticulata) in Trinidad and Tobago: evidence for a dynamic source-sink metapopulation structure, founder events and population bottlenecks. J. Evol. Biol. 22(3):485-497. http://dx.doi.org/10.1111/j.14209101.2008.01675.x
BLAKE, R.W., KWOK, P.Y.L. \& CHAN, K.H.S. 2007. The energetics of rheotactic behaviour in Pterygoplichthys spp. (Teleostei : Loricariidae). J. Fish Biol. 71(2):623-627. http://dx.doi.org/10.1111/j.10958649.2007.01512.x

CABLE, J. \& VAN OOSTERHOUT, C. 2007. The role of innate and acquired resistance in two natural populations of guppies (Poecilia reticulata) infected with the ectoparasite Gyrodactylus turnbulli. Biol. J. Linnean Soc. 90(4):647-655.

CRISPO, E., BENTZEN, P., REZNICK, D.N., KINNISON, M.T. \& HENDRY, A.P. 2006. The relative influence of natural selection and geography on gene flow in guppies. Mol. Ecol. 15(1):49-62. http://dx.doi.org/10.1111/ j.1365-294X.2005.02764.X

CROFT, D.P., ALBANESE, B., ARROWSMITH, B.J., BOTHAM, M., WEBSTER, M. \& KRAUSE, J. 2003. Sex-biased movement in the guppy (Poecilia reticulata). Oecologia 137(1):62-68. http://dx.doi.org/10.1007/ s00442-003-1268-6

DARDEN, S.K. \& CROFT, D.P. 2008. Male harassment drives females to alter habitat use and leads to segregation of the sexes. Biol. Lett. 4(5)449-451.

DEACON, A.E., RAMNARINE, I.W. \& MAGURRAN, A.E. 2011. How Reproductive Ecology Contributes to the Spread of a Globally Invasive Fish. PLoS ONE 6(9).

ENDLER, JA. 1980. Natural-selection on color patterns in Poecilia reticulata. Evolution 34(1):76-91.

ENDLER, J.A. 1995. Multiple-trait coevolution and environmental gradients in guppies. Trends Ecol. Evol. 10(1):22-29.

GHALAMBOR, C.K., REZNICK, D.N. \& WALKER, J.A. 2004. Constraints on adaptive evolution: The functional trade-off between reproduction and fast-start swimming performance in the Trinidadian guppy (Poecilia reticulata). Am. Nat. 164(1):38-50.

GORDON, S.P., REZNICK, D.N., KINNISON, M.T., BRYANT, M.J., WEESE, D.J., RASANEN, K., MILLAR, N.P \& HENDRY, A.P. 2009. Adaptive Changes in Life History and Survival following a New Guppy Introduction. Am. Nat. 174(1):34-45. http://dx.doi.org/10.1086/599300

HUIZINGA, M., GHALAMBOR, C.K. \& REZNICK, D.N. 2009. The genetic and environmental basis of adaptive differences in shoaling behaviour among populations of Trinidadian guppies, Poecilia reticulata. J. Evol. Biol. 22(9):1860-1866. http://dx.doi.org/10.1111/j.14209101.2009.01799.x

KODRIC-BROWN, A. \& NICOLETTO, P.F. 2005. Courtship behavior, swimming performance, and microhabitat use of Trinidadian guppies. Environ. Biol. Fishes 73:299-307.

MCCORMICK, S.D., HANSEN, L.P., QUINN, T.P., \& SAUNDERS, R.L. Movement, migration, and smolting of Atlantic salmon (Salmo salar). 1998. Can. J. Fish. Aquat. Sci. 55(Suppl. 1):77-92.

MONTGOMERY, J.C., DIEBEL, C., HALSTEAD, M.B.D. \& DOWNER, J. 1999. Olfactory search tracks in the Antarctic fish Trematomus bernacchii. Polar Biol. 21(3):151-154.

MÜLLER, K. 1954. Investigations on the Organic Drift in North Swedish Streams. Institute of Freshwater Research, Drottningholm, Sweden, Report 34, p.133-148.

NICOLETTO, P.F. 1996. The influence of water velocity on the display behavior of male guppies, Poecilia reticulata. Behav. Ecol. 7(3):272-278.

NORTHCUTT, R.G. 1997. Animal behaviour - Swimming against the current. Nature 389(6654):915-916.

REZNICK, D., BUTLER, M.J. \& RODD, H. 2001. Life-history evolution in guppies. VII. The comparative ecology of high- and low-predation environments. Am. Nat. 157(2):126-140.

SCHELKLE, B., SHINN, A.P., PEELER, E. \& CABLE, J. 2009. Treatment of gyrodactylid infections in fish. Dis. Aquat. Org. 86(1):65-75. http:// dx.doi.org/10.3354/dao02087

SYRIATOWICZ, A. \& BROOKS, R. 2004. Sexual responsiveness is condition-dependent in female guppies, but preference functions are not. BMC Ecol. 4:5. 
VAN OOSTERHOUT, C., HARRIS, P.D. \& CABLE, J. 2003. Marked variation in parasite resistance between two wild populations of the Trinidadian guppy, Poecilia reticulata (Pisces : Poeciliidae). Biol. J. Linnean Soc. 79(4):645-651.

VAN OOSTERHOUT, C., JOYCE, D.A., CUMMINGS, S.M., BLAIS, J., BARSON, N.J., RAMNARINE, I.W., MOHAMMED, R.S., PERSAD, N. \& CABLE, J. 2007. Balancing selection, random genetic drift, and genetic variation at the major histocompatibility complex in two wild populations of guppies (Poecilia reticulata). Evolution (12):1558-5646.

VAN OOSTERHOUT, C., MOHAMMED, R.S., HANSEN, H., ARCHARD, G.A., McMULLAN, M., WEESE, D.J. \& CABLE, J. 2007a. Selection by parasites in spate conditions in wild Trinidadian guppies (Poecilia reticulata). Int. J. Parasit. 37(7):805-812.
VAN OOSTERHOUT, C., SMITH, A.M., HANFLING, B., RAMNARINE, I.W., MOHAMMED, R.S. \& CABLE, J. 2007b. The guppy as a conservation model: Implications of parasitism and inbreeding for reintroduction success. Conserv. Biol. 21(6):1573-1583.

WILLING, E.M., BENTZEN, P., VAN OOSTERHOUT, C., HOFFMANN, M., CABLE, J., BREDEN, F., WEIGEL, D. \& Dreyer C. 2010. Genomewide single nucleotide polymorphisms reveal population history and adaptive divergence in wild guppies. Mol. Ecol. 19(5):968-984. http:// dx.doi.org/10.1111/j.1365-294X.2010.04528.x

WINKER, K., RAPPOLE, J.H. \& RAMOS, M.A. 1995. The use of movement data as an assay of habitat quality. Oecologia 101(2):211-216.

Received 05/04/2012

Revised 02/08/2012

Accepted 06/08/2012 